\title{
MENINGKATKAN KREATIVITAS BELAJAR SISWA PADA MATA \\ PELAJARAN IPS DENGAN MENGGUNAKAN MODEL COOPERATIVE LEARNING TIPE STAD DI KELAS \\ V SDN 105309 SIBOLANGIT
}

\author{
Risma Sitohang
}

Surel: rismasitohang@gmail.com

\begin{abstract}
ABSTRAK
Tujuan penelitian ini adalah untuk meningkatkan kreativitas belajar siswa dengan materi Perjuangan Persiapan Kemerdekaan Indonesia dengan menggunakan model Cooperative Learning Tipe STAD di kelas V SDN 105309 Sibolangit T. A 2012/2013. Objek penelitian adalah siswa/i kelas V SD yang berjumlah 35 orang siswa. Berdasarkan analisis data diperoleh pada kondisi awal rata - rata skor kreativitas belajar siswa sebesar 23,94 dan pada Siklus I Pertemuan 1 sebesar 32,11. Pada Siklus I Pertemuan 2 diperoleh rata-rata skor kreativitas belajar siswa sebesar 35,49. Pada Siklus II Pertemuan 1 diperoleh rata-rata skor kreativitas belajar siswa sebesar 41,17 dan pada Siklus II Pertemuan 2 diperoleh rata - rata skor kreativitas belajar siswa sebesar 52,63. Maka dapat disimpulkan bahwa dengan menggunakan model Cooperative Learning Tipe STAD dapat meningkatkan kreativitas belajar siswa pada mata pelajaran IPS di kelas V SDN105309 Sibolangit T. A 2012/2013.
\end{abstract}

Kata Kunci: Cooperative Learning, Kreativitas Belajar Siswa, STAD

\section{PENDAHULUAN}

Pendidikan merupakan usaha sadar dan terencana untuk mewujudkan suasana belajar dan proses pembelajaran agar peserta didik secara aktif mengembangkan potensi dirinya untuk memilki kekuatan spiritual keagamaan, pengenalan diri, kepribadian, kecerdasan, akhlak mulia serta keterampilan yang diperlukan dirinya, masyarakat, bangas dan negara (UU Sistem Pendidikan Nasional No. 20 Tahun 2003). Salah satu upaya untuk meningkatkan mutu pendidikan di sekolah ialah dengan cara melalui perbaikan proses belajar mengajar.

Dari wawancara yang sebelumnya telah dilakukan pada tanggal 12 Desember 2012 terhadap guru di SD Negeri 105309S ibolangit, diperoleh informasi bahwa kreativitas belajar siswa pada mata pelajaran IPS masih sangat rendah.

Berdasarkan hasil observasi pada kondisi awal diperoleh rata rata skor kreativitas belajar siswa sebesar 23,94 dengan tingkat kreativitas belajar siswa sangat rendah. Hal ini disebabkan karena kurangnya keaktifan siswa selama proses belajar mengajar yang berlangsung di dalam kelas. Peneliti juga menemukan beberapa faktor penghambat yang menyebabkan kreativitas belajar siswa masih tergolong rendah. Adapun faktor tersebut, antara lain: 1) siswa belum 
memilki hasrat keingintahuan yang cukup sebesar terhadap materi perjuangan persiapan kemerdekaan Indonesia; 2) siswa malu dan takut salah untuk mengajukan pertanyaan kepada guru; 3) rendahnya daya imajiansi siswa untuk membuat pertanyaan dan mengutarakan pendapat atau ide kepada guru. Setelah melihat data dan kondisi belajar siswa maka telah diperoleh faktor penghambat kreativitas belajar siswa, maka peneliti merencanakan untuk menerapkan model Cooperative Learning Tipe STAD untuk meningkatkan kreativitas belajar siswa pada mata pelajaran IPS dengan materi perjuangan persaiapan kemerdekaan Indonesia.

Bertitik tolak dari penjelasan diatas, kreativitas belajar siswa sangat penting untuk ditingkatkan didalam proses belajar mengajar, terutama dalam menguasai materi pelajaran suatu mata pelajaran. IPS merupakan mata pelajaran yang menuntut siswa perlu memilki rasa ingin tahu dalam memecahkan suatu masalah. Rasa ingin tahu sebagai salah satu indikator kreativitas menunjukkan bahwa betapa pentingnya kreativitas belajar siswa ditingkatkan. Guru selaku pembimbing perlu menerapkan model pembelajaran yang tepat bagi siswa. Dalam menumbuhkan kreativitas belajar siswa tersebut. Untuk meningkatkan kreativitas siswa tersebut maka model pembelajaran yang tepat adalah dengan menggunakan model Cooperative Learning tipe STAD.
Dengan menggunakan model Cooperative Learning Tipe STAD mampu memberikan kesempatan belajar lebih aktif kepada siswa, sehingga siswa dapat berpikir secara optimal dalam berargumentasi. Selain itu, melalui pembelajaran kooperatif juga siswa akan terlatih untuk berinteraksi dengan teman sekelasnya. Sedangkan guru menjadi fasilitator dan motivator dalam pembelajaran Dengan demikian mampu memunculkan kreativitas belajar siswa.

Uraian di atas menjelaskan bahwa dengan menggunakan model Cooperative Learning Tipe STAD dapat meningkatkan kreativitas belajar siswa, prediksi ini dapat dilakukan dengan melaksanakan penelitian yang berjudul: “ Meningkatkan Kreativitas Belajar Siswa pada Mata Pelajaran IPS dengan Menggunakan Model Cooperative Learning Tipe STAD di Kelas V SDN 105309 Sibolangit T. A 2012/2013".

\section{METODE PENELITIAN}

Lokasi penelitian di SD Negeri 105309 Sibolangit, J1 Jamin Ginting pada tanggal 21 Januari 2013. Penelitian ini adalah penelitian tindakan kelas. Rumusan masalah dalam penelitian ini adalah "Apakah dengan menggunakan Model Cooperative Learning Tipe STAD dapat Meningkatkan Kreativitas Belajar Siswa Pada Mata Pelajaran IPS dengan materi Perjuangan Mempersiapkan Kemerdekaan 
Indonesia di kelas V SDN 105309 Sibolangit T. A 2012/2013?”.

Tujuan penelitian adalah untuk untuk mengetahui peningkatan kreativitas belajar siswa pada mata pelajaran IPS melalui Model Cooperative Learning Tipe STAD dengan Materi Perjuangan Persiapan Kemerdekaan Indonesia di Kelas V SDN 105309 Sibolangit T.A 2012/2013. Populasi penelitian adalah seluruh siswa Kelas V Semester II di SD Negeri 105309 Sibolangit T.A 2012/2013. Adapun yang menjadi variabel dalam penelitian ini adalah: Variabel bebas dalam penelitian ini adalah penggunaan model Cooperative Learning Tipe STAD, sedangkan yang menjadi Variabel terikat pada penelitian ini adalah Kreativitas Belajar Siswa.

Pada tindakan siklus I dan siklus II, peneliti bertindak selaku guru pelaksana kegiatan pembelajaran di kelas dengan menerapkan metode eksperimen sedangkan guru kelas $\mathrm{V}$ bertindak selaku observer (pengamat) yang mengamati berlangsungnya pelaksanaan kegiatan pembelajaran yang dilakukan dan mengamati keaktifan belajar siswa selama pembelajaran berlangsung. Kegiatan yang dilaksanakan dalam tahap ini adalah melaksanakan tindakan sesuai dengan yang telah direncanakan, berupa pelaksanaan proses pembelajaran sesuai dengan rencana pelaksanaan pembelajaran. Pelaksanaan tindakan kelas siklus I dilakukan selama dua kali pertemuan dengan langkah-langkah pelaksanaan tindakan sebagai berikut:

\section{Pertemuan I}

1. Kegiatan Awal:

Pada kegiatan awal: guru memberi salam; berdoa sebelum memulai kegiatan pembelajaran; guru mengabsensi kehadiran siswa; guru melakukan apersepsi.

\section{Kegiatan Inti:}

Siswa melaksanakan model Cooperative Learning Tipe STAD dengan langkah- langkah sebagai berikut: guru memotivasi siswa; guru menyampaikan tujuan pembelajaran yang akan dicapai; guru menjelaskan materi pelajaran; guru membagi siswa menjadi beberapa kelompok; guru memberikan materi pembahasan setiap kelompok; melaksanakan kerja kelompok; guru membimbing siswa dalam melaksanakan presentasi hasil kerja kelompok; guru membagikan soal kuis dan memberikan penghargaan terhadap kelompok terbaik.

\section{Kegiatan Akhir:}

Guru menyimpulkan hasil dari kegiatan eksperimen yang telah dilaksanakan siswa; guru menilai hasil kegiatan eksperimen siswa; guru memberikan motivasi kepada siswa; guru memberikan tugas (PR) kepada siswa; guru mengucapkan salam penutup. 
Pertemuan II

\section{Kegiatan Awal:}

Pada kegiatan awal: guru memberi salam; berdoa sebelum memulai kegiatan pembelajaran; guru mengabsensi kehadiran siswa; guru melakukan apersepsi. Kemudian guru memperhatikan beberapa indikator kreativitas belajar siswa yang belum tercapai dengan baik. Agar guru bisa memfokuskan pada peningkatan kreativitas belajar siswa.

\section{Kegiatan Inti:}

Siswa melaksanakan model Cooperative Learning Tipe STAD dengan langkah- langkah sebagai berikut: guru memotivasi siswa; guru menyampaikan tujuan pembelajaran yang akan dicapai; guru menjelaskan materi pelajaran; guru membagi siswa menjadi beberapa kelompok; guru memberikan materi pembahasan setiap kelompok; melaksanakan kerja kelompok; guru membimbing siswa dalam melaksanakan presentasi hasil kerja kelompok; guru membagikan soal kuis dan memberikan penghargaan terhadap kelompok terbaik. Selama kegiatan pemebelajaran berlangsung peneliti dbantu oleh guru kelas dalam melakukan observasi selama kegiatan pembelajaran berlangsung.

\section{Kegiatan Akhir:}

Guru menyimpulkan hasil dari kegiatan eksperimen yang telah dilaksanakan siswa; guru menilai hasil kegiatan eksperimen siswa; guru memberikan motivasi kepada siswa; guru memberikan tugas (PR) kepada siswa; guru mengucapkan salam penutup.

\section{HASIL DAN PEMBAHASAN Hasil Penelitian}

Dari data hasil observasi di atas dapat dilihat bahwa kreativitas belajar siswa dari setiap siswa mengalami peningkatan yang sangat baik. Berikur rata - rata peningkatan skor kreativitas belajar siswa mulai dari Kondisi Awal sampai, kegiatan Siklus I hingga kegiatan siklus II dapat dilihat pada tabel di bawah ini :

Tabel Rekapitulasi Skor Kreativitas Belajar Siswa Siklus I dan Siklus I

\begin{tabular}{|c|c|c|c|c|c|c|}
\hline \multirow{2}{*}{ No. } & \multirow{2}{*}{$\begin{array}{c}\text { Nomor } \\
\text { Responden }\end{array}$} & \multirow{2}{*}{ Kondisi Awal } & \multicolumn{2}{|c|}{ Siklus I } & \multicolumn{2}{c|}{ Siklus II } \\
\cline { 3 - 7 } & & Pert. 1 & Pert. 2 & Pert. 1 & Pert. 2 \\
\hline 1 & 01 & 20 & 23 & 27 & 41 & 51 \\
\hline 2 & 02 & 29 & 35 & 36 & 42 & 53 \\
\hline 3 & 03 & 30 & 30 & 34 & 44 & 51 \\
\hline 4 & 04 & 32 & 38 & 41 & 44 & 59 \\
\hline 5 & 05 & 26 & 33 & 36 & 41 & 46 \\
\hline 6 & 06 & 30 & 42 & 39 & 42 & 49 \\
\hline
\end{tabular}


ESJ VOLUME 5, NO. 2, JUNI 2016

\begin{tabular}{|c|c|c|c|c|c|c|}
\hline 7 & 07 & 26 & 27 & 28 & 36 & 56 \\
\hline 8 & 08 & 45 & 48 & 48 & 51 & 58 \\
\hline 9 & 09 & 15 & 17 & 19 & 27 & 58 \\
\hline 10 & 10 & 15 & 21 & 25 & 31 & 38 \\
\hline 11 & 11 & 21 & 43 & 42 & 44 & 52 \\
\hline 12 & 12 & 44 & 48 & 49 & 52 & 59 \\
\hline 13 & 13 & 15 & 17 & 23 & 26 & 29 \\
\hline 14 & 14 & 18 & 21 & 26 & 26 & 58 \\
\hline 15 & 15 & 17 & 21 & 25 & 29 & 59 \\
\hline 16 & 16 & 15 & 22 & 27 & 42 & 57 \\
\hline 17 & 17 & 24 & 30 & 35 & 46 & 52 \\
\hline 18 & 18 & 16 & 42 & 43 & 48 & 53 \\
\hline 19 & 19 & 15 & 22 & 27 & 37 & 56 \\
\hline 20 & 20 & 19 & 31 & 36 & 34 & 54 \\
\hline 21 & 21 & 17 & 24 & 32 & 44 & 58 \\
\hline 22 & 22 & 15 & 22 & 30 & 40 & 58 \\
\hline 23 & 23 & 15 & 42 & 47 & 49 & 56 \\
\hline 24 & 24 & 39 & 39 & 47 & 39 & 56 \\
\hline 25 & 25 & 15 & 20 & 34 & 37 & 54 \\
\hline 26 & 26 & 17 & 20 & 33 & 43 & 55 \\
\hline 27 & 27 & 24 & 43 & 30 & 50 & 58 \\
\hline 28 & 28 & 32 & 42 & 42 & 49 & 59 \\
\hline 29 & 29 & 16 & 30 & 41 & 47 & 52 \\
\hline 30 & 30 & 42 & 49 & 48 & 54 & 59 \\
\hline 31 & 31 & 37 & 48 & 47 & 47 & 58 \\
\hline 32 & 32 & 24 & 42 & 42 & 47 & 54 \\
\hline 33 & 33 & 42 & 48 & 48 & 50 & 58 \\
\hline 34 & 34 & 15 & 21 & 30 & 36 & 33 \\
\hline 35 & 35 & 16 & 23 & 25 & 26 & 26 \\
\hline \multicolumn{2}{|c|}{ Jumlah Skor } & 838 & 1124 & 1242 & 1441 & 1842 \\
\hline \multicolumn{2}{|c|}{ Rata - Rata Skor } & 23,94 & 32,11 & 35,49 & 41,17 & 52,63 \\
\hline \multicolumn{2}{|c|}{ Tingkat Kreativitas } & Sangat Rendah & Rendah & Rendah & Tinggi & Tinggi \\
\hline
\end{tabular}


Untuk lebih lengkapnya dapat dilihat dari deskripsi histogram skor peningkatan kreativitas belajar siswa pada tiap siklus berikut ini:

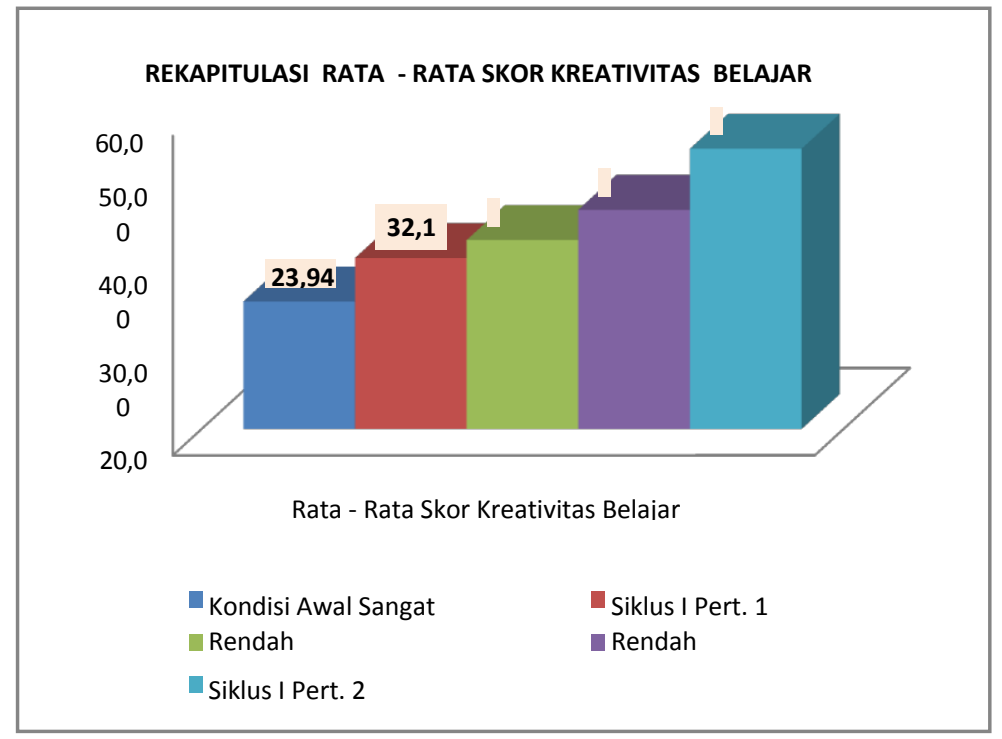

Dengan maenggunakan model Cooperative Learning Tipe STAD dalam kegiatan pembelajaran disimpulkan bahwa kreativitas $\mathrm{n}$ belajar siswa mengalami peningkatan pada Mata pelajaran IPS dengan materi Perjuangan Persiapan Kemerdekaan Indonesia. Untuk mendukung penjelasan di atas dapat dilihat pada tabel rekapitulasi ratarata peningkatan skor kreativitas belajar siswa dari Kondisi Awal, Siklus I dan Siklus II di atas. Berdasarkan analisis data observasi pada Kondisi Awal terdapat 5 orang siswa dengan rata - rata skor kreativitas sebesar 6,06 dengan tingkat kreativitas tinggi (38-57). Dan 6 orang siswa dengan rata - rata skor sebesar 5,43 dengan tingkat kreativitas rendah (28-37). Serta sebanyak 24 orang siswa dengan rata - rata skor kreativitas sebesar 12,46 dengan tingkat kreativitas sangat rendah (15-27). Siklus I pertemuan 1 terdapat 14 orang siswa dengan rata rata skor kreativitas sebesar 17,54 dengan tingkat kreativitas tinggi (3857). Dan sebanyak 6 orang siswa dengan rata - rata skor kreativitas sebesar 5,40 dengan tingkat kreativitas rendah (28-37). Serta 15 orang siswa dengan rata - rata skor kreativitas sebesar 9,17 dengan tingkat kreativitas sangat rendah (1527). Pada siklus I pertemuan 2 mengalami perubahan yaitu terdapat 14 orang siswa dengan rata - rata skor kreativitas belajar sebesar 17,83 dengan tingkat kreativitas tinggi (3857).

Dan 12 orang siswa dengan rata - rata skor kreativitas belajar sebesar 11,26 dengan tingkat kreativitas rendah. Sementara sebanyak 9 orang siswa dengan rata rata skor kreativitas sebesar 6,40 dengan tingkat kreativitas sangat 
rendah (15-27). Pada siklus II pertemuan 1 terdapat 24 orang siswa dengan rata - rata skor kreativitas sebesar 31,31 dengan tingkat kreativitas tinggi (38-57). Sementara 7 orang siswa dengan rata - rata skor kreativitas sebesar 6,86 dengan tingkat kreativitas rendah (28-37). Serta 4 orang siswa dengan rata - rata skor kreativitas sebesar 3,00 dengan tingkat kreativitas sangat rendah (1527). Pada siklus II pertemuan 2 kreativitas belajar siswa semakin meningkat, yaitu terdapat 13 orang siswa dengan rata-rata skor kreativitas sebesar 21,69 dengan tingkat kreativitas tinggi (58-60). Sebanyak 19 orang siswa dengan rata - rata skor kreativitas sebesar 28,43 dengan tingkat kreativitas tinggi (3857). Dan sebanyak 2 orang siswa dengan rata - rata skor kreativitas sebesar 1,77 dengan tingkat kreativitas rendah (28-37) serta 1 orang siswa dengan rata - rata skor kreativitas sebesar 0,74 denga tingkat kreativitas sangat rendah (15-27).

\section{Pembahasan}

Tujuan penelitian adalah untuk mengetahui penggunaan metode eksperimen dalam meningkatkan kreativitas belajar siswa pada mata pelajaran IPS dengan Materi Perjuangan Persiapan Kemerdekaan Indonesia di Kelas V SD Negeri 105309 Sibolangit T. A 2012/2013.

Pada siklus I pertemuan 1 kreativitas belajar siswa pada mata pelajaran IPS masih rendah dengan rata - rata skor kreativitas belajar siswa secara klasikal yaitu 32,11. Dan pada siklus I pertemuan 2 rata rata skor kreativitas belajar siswa secara klasikal adalaha 35,49. Upaya yang harus dilakukan untuk meningkatkan kreativitas belajar siswa yaitu peneliti harus mengoptimalkan proses pembelajaran kepada siswa dengan untuk materi perjuangan persiapan kemerdekaan Indonesia melalui model Cooperative Learning Tipe STAD.

Selanjutnya peneliti melaksanakan siklus II sebagai perbaikan dari siklus I untuk melihat perkembangan tingkat kreativitas belajar siswa pada mata pelajaran IPS dengan materi perjuangan persiapan kemerdekaan Indonesia dengan menggunakan model Cooperative Learning Tipe STAD. Pada Siklus II pertemuan 1 kreativitas belajar siswa sudah mengalami peningkatan rata rata skor kreativitas belajar siswa secara klasikal sebesar 41,17. Dan pada Siklus II pertemuan 2 diperoleh skor kreativitas belajar siswa sebesar 52,63. Hal ini menunjukkan bahwa pelakasanaan kegiatan proses belajar mengajar telah berhasil meningkatkan kreativitas belajar siswa.

$$
\text { Penggunaan model }
$$

Cooperative Learning Tipe STAD dalam penelitian ini dapat meningkatkan kreativitas belajar siswa dengan materi perjuangan persiapan kemerdekaan Indonesia pada mata pelajaran IPS. Dengan digunakannya model Cooperative Learning Tipe STAD juga mampu memberi motivasi belajar bagi siswa sesuai dengan materi pembelajaran 
yang sedang dibahas. Selain itu, melalui model pembelajaran ini siswa dapat menumbuhkan daya imajinasi siswa dalam belajar untuk mengemukakan pertanyaan dan memberikan pertanyaan sebagai bentuk rasa ingin tahu siswa terhadap materi pelajaran yang dang dibahas.

Dengan demikian berdasarkan hasil penelitian yang dilakukan di SDN 105309 Sibolangit bagi siswa kelas V SD dengan materi perjuangan persiapan kemerdekaan Indonesia dengan menggunakan model Cooperative Learning Tipe STAD dapat meningkatkan kreativitas belajar siswa pada mata pelajaran IPS.

\section{KESIMPULAN}

Berdasarkan hasil penelitian dan pengamatan data penelitian yang diperoleh terhadap penigkatan kreativitas belajar siswa kelas V SDN 105309 Sibolangit dengan materi perjuangan persiapan kemerdekaan Indonesia. Maka kesimpulan dari penelitian ini adalah:

1. Dengan menggunakan model Cooperative Learning Tipe STAD pada mata pelajaran IPS dengan materi perjuangan persiapan kemerdekaan Indonesia dapat meningkatkan kreativitas belajar siswa kelas V SDN 105309 Sibolangit Tahun Ajaran 2012/2013.

2. Rata - rata skor kreativitas belajar siswa pada mata pelajaran IPS dengan materi perjuangan persiapan kemerdekaan Indonesia pada kondisi awal sebesar 23,94 dan pada Siklus I Pertemuan 1 dengan rata - rata skor kreativitas belajar siswa sebesar 32,11. Pada Siklus I Pertemuan 2 diperoleh rata - rata skor kreativitas belajar siswa adalah 35,49.

3. Pada Siklus II Pertemuan 1 diperoleh rata - rata skor kreativitas belajar siswa sebesar 41,17 dan pada Siklus II Pertemuan 2 diperoleh rata - rata skor kreativitas belajar siswa sebesar 52,63.

\section{DAFTAR RUJUKAN}

Akbar, Reni, Wihardjo dan Wiyono. 2001. Kreativitas. Jakarta: Grasindo.

Arikunto, Suharsimi. 2008. Penelitian Tindakan Kelas. Jakarta: Bumi Aksara.

Dewi, $\quad 2010$. Profesionalisasi Guru Melalui Penelitian Tindakan Kelas. Medan: Pasca Sarjana Unimed.

Isjoni, $\quad 2009$. Pembelajaran Kooperatif. Yogyakarta: Pustaka Pelajar.

Munandar, Utami. 2009. Pengembangan Kreativitas Anak Berbakat. Jakarta: Rineka Cipta.

Slameto. 2009. Belajar dan Faktorfaktor yang Mempengaruhinya. Jakarta: Rineka Cipta.

Slavin, Robert. 2009. Cooperative Learning. Jakarta: Nusamedia. 
Sukidin, dkk. Manajemen Penelitian Tindakan Kelas. Jakarta: Insan Cendikia.

Supriadi, Dedi. 1994. Kreativitas, Kebudayaan dan Perkembangan IPTEK. Bandung: Alfabeta.

Suryosubroto, B. 2009. Proses Belajar Mengajar di Sekolah. Jakarta: Rineka Cipta.

Suslianingsih, Endang, dkk. 2007. Ilmu Pengetahuan Sosial untuk SD/MI kelas V. Jakarta: BSE.

Trianto. 2011. Mendesain Model Pembelajaran Inovatif Progresif. Surabaya: Kencana.

Wardani, I.G.A.K, Wihardit dan Nasoetion. 2007. Penelitian Tindakan Kelas. Jakarta: Universitas Terbuka. 
